\title{
The journey of a profession: An introduction
}

\section{Liz Beddoe}

Liz Beddoe, Head of the School of Counselling, Human Services and Social Work, University of Auckland, former Editor of Social Work Review (1986-93).

Ritchie, Prof. James E. (1967). The relation of the university to the profession of social work. New Zealand Social Worker: News and Opinions, 3(4), 3-13.

Professor Ritchie's article, now 42 years old, addresses issues that remain significant for our profession in 2009. It was published in the New Zealand journal under its first title: New Zealand Social Worker: News and Opinions. The article is accompanied by a photograph of members of the Waikato Branch of NZASW, the women smartly attired in dresses and heels, the men in jacket and tie. It seems likely that the article is the text of a talk given by Professor Ritchie to the branch, during a period when the young NZASW was lobbying for further opportunities for education and training for social workers. James Ritchie was the University of Waikato's first Professor of Psychology and well known author of 'Growing up in New Zealand,' with Jane Ritchie (1978) and the influential 'Becoming bicultural' (1992).

In this article he discusses the challenges facing a very young professional association as it strives to develop a professional foundation for social work. He rightly points out that a university qualification alone does not justify a claim for professional status. Membership of a profession, he asserts, requires 'an agreed system of ethics', a 'sense of vocation' and a lifetime commitment to the aims of the profession and the understanding that one is never 'off duty' (p.5). It is notable that this issue of 'the $24 / 7$ social worker' and their offduty conduct (see McLaughlin, 2007, p. 1274) has been more contentious since the advent of statutory registration.

Ritchie also acknowledges the importance of the university in the socialisation of new entrants to the profession: the processes of 'un-learning', experiencing new learning and the construction of a new identity. We might find his drawing parallels with this to Goffman's work on total institutions, Asylums, rather alarming, given our current aspiration to encourage students to critically reflect and question practice, however there is a consensus that education should turn out graduates with a set of predictable knowledge(s), skills, values and dispositions. Just what that knowledge set is, who determines its features, which dispositions are the 'right' ones, and how all this is transmitted remains a site of struggle and debate (Nash \& Munford, 2001).

In my view the major contribution made in Professor Ritchie's article is his discussion of the best education for social work. His prescription to build a strong profession is for social workers to gain a four-year undergraduate degree, followed by a two-year postgraduate social work programme, and then a one-year internship (p.11). 
So, four decades later where did we get to? Daniels cites Levett as showing that only about 14\% of social workers held a qualification in 1969 (Daniels, 1973, p.47). In 1981 a larger study reported only $12 \%$ of social workers had a social work qualification (Rochford \& Robb, 1981). It is now very difficult to get any broad figures to compare, but we can assume that the overall percentage of qualified social workers is much higher, perhaps $60 \%$ (based on anecdotal information), but the majority would hold a diploma as their highest social work qualification. We currently have recognised programme at 16 institutions, in five universities, in two wananga and nine polytechnics.

So many programmes yet still at least a moderate shortage of qualified social workers and an aging workforce. Agencies are still employing unqualified workers.

Where will we be in $2047 ?$

\title{
References
}

Daniels, K. (1973). Social work education: A time of crisis. The New Zealand Social Worker: News and Opinions, 9(4), 43-55.

McLaughlin, K. (2007). Regulation and risk in social work: The General Social Care Council and the Social Care Register in context. British Journal of Social Work, 37(7), 1263-1277.

Nash, M., \& Munford, R. (2001). Unresolved struggles: Educating social workers in Aotearoa New Zealand. Social Work Education, 20(1), 21-34.

Ritchie, J.E. (1967). The relation of the university to the profession of social work. New Zealand Social Worker: News and Opinions, 3(2), 3-13.

Ritchie, J. (1992). Becoming bicultural. Wellington: Huia Publishers: Daphne Brasell Associates.

Ritchie, J., \& Ritchie, J. (1978). Growing up in New Zealand. Hornsby, NSW: Boston: George Allen and Unwin Australia.

Rochford, M. W., \& Robb, M. J. (1981). People in the social services. Wellington: New Zealand Social Work Training Council.

\section{The relation of the university to the profession of social work}

\author{
James E. Ritchie
}

At the risk of seeming academic and pedantic I would like to attempt at the outset to clarify (in my own mind at least), just what is meant by membership in a profession. I want to do this in the first instance because many people have the erroneous idea that for a profession to be established as such and for a person to claim professional status all that is needed is some qualification from a university or professional college. This attitude has led to a continuing and increasing demand on universities, here as elsewhere, to accommodate or adapt to their courses in ways which are not always in the best interests of university education or necessarily likely to achieve the objects of the profession. In some cases the universities have acted almost without consultation with the relevant professional association, in other cases rejected quite proper professional demands.

Within the last few years we have seen management, nursing, optometry, correctional clinical and educational psychology and a number of other cases for professional training 